\title{
In Situ Hydrogel Formulation for Intra-Articular Application of Diclofenac Sodium-Loaded Polymeric Nanoparticles
}

\author{
Diklofenak Sodyum Yüklü Polimerik Nanopartiküllerin İntra-Artiküler \\ Uygulaması İçin In Situ Hidrojel Formülasyonu
}

Berrin KÜÇÜKTÜRKMEN, Umut Can ÖZ, Asuman BOZKIR*

Ankara University, Faculty of Pharmacy, Department of Pharmaceutical Technology, Ankara, Turkey

\begin{abstract}
Objectives: The world's population is getting older and the number of people suffering from arthritis is a major problem according to World Health Organization's data. In this respect, the need for more efficient treatment for arthritis becomes an urgent issue. In this research, nanoparticle bearing in situ gelling hydrogel formulation was developed for prolonged local delivery of diclofenac sodium (DS).

Materials and Methods: Emulsion-solvent evaporation technique was used for the preparation of nanoparticles. Particle size, encapsulation efficiency, morphology, and drug release profile of DS loaded biodegradable nanoparticles as well as gel viscosity and gelation time of in situ gelling hydrogel formulations were optimized to increase the time interval between each dose application for enhanced patience compliance.

Results: The spherical nanoparticles with a mean particle diameter of $168 \mathrm{~nm}$ was obtained and confirmed by both transmission electron microscope and atomic force microscope. Different types of surfactants were tested in the first emulsification step of nanoparticle production process and Arlace ${ }^{\circledR}-\mathrm{C}$ significantly increased the encapsulation efficiency to $89.7 \%$. Thirty days prolonged in vitro release of DS was achieved by using the combined formulation of polymeric nanoparticles and in situ hydrogel prepared by using poloxomer 407 and chitosan.

Conclusion: Local administration of DS with this novel delivery system could be considered of having potential to minimize side effects associated with decreased amount of drug in dosage form compared to conventional oral dose.
\end{abstract}

Key words: Diclofenac sodium, drug delivery, PLGA, Poly( $\varepsilon$-caprolactone), thermosensitive hydrogel, poloxamers

Öz

Amaç: Dünya Sağlık Örgütü'nün verilerine göre dünya çapında insanların yaş ortalaması ve bağlantılı olarak artrit hastalığından mağdur olan insan sayısı da artmaktadır. Bu açıdan bakıldığında, artrit tedavisi için daha etkili tedavilerin gerekliliği önemli hale gelmiștir. Bu araştırmada, diklofenak sodyumun (DS) uzatılmış lokal taşınımı için nanopartikül içeren in situ hidrojel formülasyonları geliştirilmiştir.

Gereç ve Yöntemler: Nanopartiküllerin hazırlanmasında emülsiyon-çözücü buharlaştırma yöntemi kullanılmıştır. DS yüklü nanopartiküllerin partikül büyüklüğü, enkapsülasyon etkinliği, morfolojisi ve ilaç salım profilleri ile in situ hidrojelin jel viskozitesi ve jelleșme süresi, hasta uyuncunu artırmak için her bir dozun uygulanması arasındaki zamanı artırmak amacıyla optimize edilmiştir.

Bulgular: Ortalama partikül büyüklüğü $168 \mathrm{~nm}$ olan küresel nanopartiküller elde edilmiş ve geçirimli elektron mikroskobu ve atomik kuvvet mikroskobu ile desteklenmiștir. Nanopartikül üretim sürecinin ilk emülsifikasyon adımında farklı sürfaktanlar denenmiș ve Arlacel ${ }^{\circledR}-C$ diklofenak sodyumun enkapsülasyon etkinliğini \%89.7'ye yükseltmiştir. DS'nin 30 güne uzatılmış in vitro salımı, nanopartiküllerin ve poloksamer 407/kitozan ile hazırlanmış in situ hidrojelin kombine kullanılmasıyla başarılmışır.

Sonuç: DS'nin bu yenilikçi taşıyıcı sistem ile lokal uygulanmasının, konvansiyonel oral dozaj formuna göre azaltılmış miktarda etkin madde içermesinden dolayı yan etkileri minimize etme potansiyeline sahip olduğu düşünülmüștür.

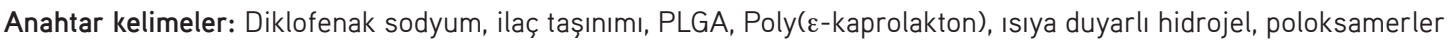

*Correspondence: E-mail: bozkir@pharmacy.ankara.edu.tr, Phone: +90 3122033153

Received: 04.08.2016, Accepted: 01.09.2016

๑Turk J Pharm Sci, Published by Galenos Publishing House. 


\section{INTRODUCTION}

Biodegradable nanoparticulate drug delivery systems are becoming more common each day because of their advantages such as enhanced drug stability, targeted delivery to any desired cell or tissue, and modified release. Poly(lactic-co-glycolic acid) (PLGA) and poly( $\varepsilon$-caprolactone) (PCL) are two major examples of polyester based polymer family and usually preferred to formulate nanoparticle based drug delivery systems due to their biodegradation to non-toxic and biodegradable monomers. By the approval of United States Food and Drug Administration, ${ }^{1,2}$ they have started to used in market and brought immense potential as a drug delivery carrier.

The pathological situation called arthritis affects most of the middle aged population who are over 45 years old. The most common ways of arthritis treatment include the application of oral non steroidal anti-inflammatory drugs, intra-articular medications and surgical interventions. The arthritis patients usually have difficulties during the application of intraarticular medications which are the most preferred treatment among physicians. Utilization of micro- and nano-particles provides enhanced retention time of the medication at joint area, maintains the drug concentration at a desired level via controlled release mechanism and eliminated the potential side effects of the drug by low dose treatment. Elron-Gross et al. $^{3}$ proved that intra-articular application of diclofenac sodium (DS) loaded microparticle containing hyaluronan based hydrogel formulation was significantly increased the retention time and therapeutic effect remained stable with lower drug amount compared to conventional oral dose of the drug. The gelation could be achieved with Poloxamer 407 and Poloxamer 188 polymers in thermosensitive hydrogel formulations due to their unique characteristics. ${ }^{4}$

Several polymeric microparticle and nanoparticle systems have been attempted with the goal of increasing the retention time of therapeutic agents within the joint cavity. However, nanoparticles rapidly escape from the joint cavity and microsized particulates are prone to phagocytosis by macrophages in synovial linings. ${ }^{5}$ Recently, in situ forming hydrogels was introduced as an alternative tool to increase the retention time in joints.

In situ forming hydrogels are usually applied as solutions or suspensions and undergo gelation process in the application site due to physicochemical changes such as $\mathrm{pH}$, temperature and ions. This system allows administration of accurate doses, increment of residence time and bioavailability at desired area. ${ }^{6}$ Thermosensitive in situ hydrogel systems have a liquid character below body temperature $\left(\sim 37^{\circ} \mathrm{C}\right)$ and after administration to the body, liquid state turns into a gel system. Poloxamers are widely used to prepare thermosensitive in situ hydrogel systems. Poloxamers are nonionic triblock copolymers composed of a central hydrophobic chain of polyoxypropylene [poly(propylene oxide)] flanked by two hydrophilic chains of polyoxyethylene [poly(ethylene oxide)]. Due to the dehydration of polymer blocks with temperature, non-chemically cross-linked hydrogel is formed.
The gel formation is a result of micellar enlargements and can not be set apart easily from each other, which accounts for the rigidity and high viscosity of poloxamer containing gels. ${ }^{7}$ Poloxamer-based hydrogels are biocompatible and can be administered into the body in a minimally invasive manner. Thus, these hydrogels are excellent candidates for long term therapy. ${ }^{8}$

DS, the sodium salt of o-(2,6-dichlorophenylamino)-phenyl acetic acid is a well known nonsteroidal anti-inflammatory drug. Because of having anti-inflammatory, analgesic and antipyretic pharmacological effects, it is widely used in the treatment of osteoarthritis, rheumatoid arthritis and ankylosing spondylitis which leads a quite uncomfortable life especially among elder population. DS is absorbed quickly and almost completely with oral administration and also its terminal plasma half life is as short as 1-2 hours.? These physicochemical properties reveal some problems in the treatment procedure such as the requirement of repeated per oral administrations of DS. However, frequently repeated per oral administrations of DS may cause adverse effects at gastrointestinal system. ${ }^{10}$ Therefore, new drug delivery strategies are needed for local delivery of DS.

The main purpose of this research is to develop in situ gelling hydrogel formulations containing DS loaded nanoparticles. DS loaded nanoparticles were prepared by using PLGA and PCL as polymer and characterized in terms of particle size, morphology, encapsulation efficiency and in vitro drug release. Then, in situ gelling hydrogel formulations containing DS loaded nanoparticles were prepared with Poloxamer 407 and chitosan. In vitro nanoparticle properties such as particle size, zeta potential, particle morphology, drug encapsulation efficiency, drug release profiles and gelation temperature, $\mathrm{pH}$, viscosity features of in situ gelling hydrogel formulations were evaluated and optimized for a better arthritis treatment.

\section{EXPERIMENTAL}

\section{Materials}

DS was kindly provided by Novartis ${ }^{\circledR}$ (Turkey). Poloxamer 407, Poloxamer 188, PLGA (lactide: glycolide 50:50, Mw 24.00038,000), Poly ( $\varepsilon$-caprolactone) (PCL, Mw 70.000-90.000), Chitosan (medium molecular weight, 75-85\% deacetylated), Polyvinyl alcohol (PVA) (PVA, Mw 30.000-70.000), Arlace ${ }^{\circledR}-\mathrm{C}$ (sorbitan sesquioleate), and dichloromethane (DCM) (DCM, analytical grade) were purchased from Sigma-Aldrich (Germany). Tween 80 was purchased from Merck (Germany). All other chemicals used were of analytical grade.

\section{Methods}

\section{Preparation of nanoparticles}

Modified water/oil/water $\left(\mathrm{W}_{1} / \mathrm{O} / \mathrm{W}_{2}\right)$ emulsion-solvent evaporation technique was used for the preparation of nanoparticles. ${ }^{11,12}$ Briefly, $100 \mathrm{mg}$ of polymer/polymer mixtures (1:1) of PCL and PLGA were dissolved in $2 \mathrm{~mL}$ of DCM to form $O$ phase of the multiple emulsion. DS $(75 \mathrm{mg}$ ) was separately dissolved in $1 \mathrm{~mL}$ of $\mathrm{pH} 5.8$ or $\mathrm{pH} 7.4$ aqueous buffer solution 
to form $W_{1}$ phase. The primary emulsion $\left(W_{1} / O\right)$ was obtained by directly pouring $\mathrm{O}$ phase on $\mathrm{W}_{1}$ phase and sonication of this mixture for $1 \mathrm{~min}$ at $100 \%$ amplitude. $\mathrm{W}_{2}$ phase was formed via solubilizing different stabilizers $(1 \% \mathrm{w} / \mathrm{v})$ in $10 \mathrm{~mL}$ of various buffer solutions ( $\mathrm{pH} 5.8$ or pH 7.4 phosphate buffers). Finally, primer emulsion was poured quickly into the $\mathrm{W}_{2}$ phase then sonicated for $2 \mathrm{~min}$ at $100 \%$ amplitude to generate $\mathrm{W}_{1} / \mathrm{O} / \mathrm{W}_{2}$ emulsion. After formation of the multiple emulsion, DCM was evaporated via magnetic stirring overnight. The final multiple emulsion was centrifuged $(40.000 \times \mathrm{g})$ at $10^{\circ} \mathrm{C}$ for $30 \mathrm{~min}$ then washed with $10 \mathrm{~mL}$ fresh $W_{2}$ phase three times to get rid of surface attached DS molecules and nanoparticles were collected after 24 hours of lyophilisation.

Tween 80 which has an important role to form primary emulsion was added to $W_{1}$ phase $\left(25 \% \mathrm{v} / \mathrm{v}\right.$ of $1 \mathrm{~mL} \mathrm{~W}_{1}$ phase) in the preparation method of F1-F5. On the other hand, Arlace ${ }^{\circledR}-\mathrm{C}$ was added to $O$ phase ( $10 \% \mathrm{v} / \mathrm{v}$ of $2 \mathrm{~mL} O$ phase) during the formulation of $\mathrm{F} 6$ instead of adding Tween 80 to $\mathrm{W}_{1}$ phase.

\section{Particle size, polydispersity index and zeta potential}

A sample of $10 \mu \mathrm{L}$ of nanoparticles was diluted with ultrapure water to $2 \mathrm{~mL}$. The size distribution and zeta potential were evaluated at $25^{\circ} \mathrm{C}$ via differential light scattering method using Malvern Zetasizer ${ }^{\circledR}$ Nano ZS (Malvern Instruments, UK).

\section{Encapsulation efficiency}

Encapsulation efficiencies of the nanoparticle formulations were determined via indirect method. Briefly, each supernatant fraction collected during washing step at nanoparticle production procedure, stored in a flask and $1 \mathrm{~mL}$ supernatant was removed from this flask to determine the amount of nonencapsulated DS via ultraviolet (UV) spectroscopy (Shimadzu DV-1601) at $268 \mathrm{~nm}$. After non-encapsulated DS amount was found, this amount was subtracted from the whole DS amount used at nanoparticle production procedure and encapsulated amount of DS was determined. Encapsulation efficiency was calculated using the Equation 1.

Encapsulation Efficiency $(\%)=$ amount of drug in the nanoparticles $(\mathrm{mg}) /$ initial amount of drug $(\mathrm{mg}) \times 100$

(Equation 1)

\section{Preparation and characterization of in situ hydrogel system}

Thermosensitive poloxamer gels were prepared according to the cold method. ${ }^{13}$ Chitosan $(0.25 \% \mathrm{w} / \mathrm{v})$ and Poloxamer 407 (18\% $\mathrm{w} / \mathrm{w}$ ) polymers were used in the preparation of thermosensitive hydrogel formulation. The gelation temperature was determined based on an observation of the immobilized magnetic bar due to the gelation. ${ }^{14}$ Two grams of the prepared solution was transferred to a $5 \mathrm{~mL}$ transparent vial containing a magnetic stirring bar, the vial was heated with a constant stirring rate and the temperature at which the rotation of the bar stopped was taken as gelation temperature. The $\mathrm{pH}$ of formulation was measured with SenTix $82 \mathrm{pH}$ electrode. ${ }^{15}$ Viscosity determinations of prepared formulations were carried out on a Brookfield RVTDV-II viscometer ${ }^{16}$ using spindle T-E. Angular velocity increased gradually from 0.5 to $100 \mathrm{rpm}$. The average of three readings was used to calculate viscosity.

\section{In vitro release}

In vitro release studies from DS loaded nanoparticles, DS loaded nanoparticle bearing hydrogel and non-encapsulated DS bearing hydrogel were performed according to previously reported methods with minor modification.17,18,19 Briefly, 5 mg DS containing different nanoparticle formulations were suspended in $1 \mathrm{~mL}$ of $\mathrm{pH} 7.4$ phosphate buffer then placed in dialysis bag. For hydrogel formulations, $5 \mathrm{mg}$ of non-encapsulated DS containing hydrogel or $14 \mathrm{mg}$ of $\mathrm{F} 6$ coded nanoparticle bearing (contains $5 \mathrm{mg}$ DS) $1 \mathrm{~mL}$ hydrogel were put in dialysis bag directly without any dilution. The dialysis bag (Sigma, 1200014000 Da MWCO) was suspended in $\mathrm{pH} 7.4$ phosphate buffer (50 mL) maintained at $37 \pm 0.5^{\circ} \mathrm{C}$. The dispersion was rotated at $50 \mathrm{rpm}$ in an incubated shaker. The $1 \mathrm{~mL}$ sample were taken at each specified time interval then replaced with the same amount of fresh release medium and drug concentrations were determined by UV spectrophotometer after a certain dilution of withdrawn volume. Finally, cumulative drug release percent was calculated and each release test was repeated three times.

\section{Differential scanning calorimetry}

The physical state of DS entrapped in the nanoparticles was characterized by differential scanning calorimetry (DSC). A sample of 5-10 mg of DS, PLGA, PCL and lyophilized nanoparticle formulation was placed in a standard aluminum pan with a lid. The heating rate was set to $5^{\circ} \mathrm{C} / \mathrm{min}$ between $30-300^{\circ} \mathrm{C}$ in a differential scanning calorimeter (Shimadzu DSC-60, Japan).

Atomic force microscopy and transmission electron microscopy The morphology of the nanoparticles was investigated by atomic force microscopy (AFM) and transmission electron microscopy (TEM). AFM images were taken in tapping mode using Nanomagnetics' instrument. ${ }^{20}$ Samples were prepared by redispersion of nanoparticles in ultrapure water and placing a droplet onto a mica surface adhered to nickel disc, followed by drying under nitrogen flow. TEM images were taken using FEI Tecnai $\mathrm{G} 2$ at $300 \mathrm{kV} .{ }^{21}$ During the preparation of TEM samples, after a certain dilution, nanoparticle solutions $(10 \mu \mathrm{L})$ were placed on copper grids than left for drying at $25^{\circ} \mathrm{C}$ and viewed.

\section{Gas chromatography analysis for residual solvent detection}

Gas chromatography (GC) method was performed to detect the amount of residual DCM which was used during nanoparticle production procedure. Chromatographic test was carried out by using Agilent 6,890N Network GC System equipped with flame-ionization detector and Supelco SP-2380 $(60.0 \mathrm{~mm} x$ $0.25 \mathrm{~mm} \times 0.25 \mathrm{~mm}$ ) column. Before GC application, residual DCM was extracted from nanoparticles by using $n$-hexane via partitioning without dissolving the polymer. A particular amount of DS loaded nanoparticle was treated with n-hexane in a tube for 3 hours with vortexing. Afterwards, nanoparticles were separated by centrifuging and supernatant was injected to the column of GC device. Pure n-hexane and DCM were also injected to define each solvent's peak by itself. ${ }^{22}$

\section{Statistical analysis}

All data were expressed as mean \pm standard deviation. Student's t test was used to compare differences between 
groups. $\mathrm{P}$ values less than 0.05 were considered statistically significant. Each experiments and analyses were carried out as 3 replicates.

\section{RESULTS AND DISCUSSION}

\section{Particle size, polydispersity and zeta potential}

Nanoparticle formulations were successfully formulated with modified w/o/w emulsion-solvent evaporation technique. Nanoparticle characteristics such as particle size, polydispersity index and zeta potential were evaluated. Formulation variables are included in the Table 1. In each step only one formulation parameter has been modified compared to previous nanoparticle formulation, to observe how the modification effected on particles' characteristics in terms of average particle size, zeta potential and encapsulation efficiency.

Particle size of nanoparticles plays an important role for the penetration through physiological barriers, interaction with cell membranes and the therapeutic effect. Smaller particles have various advantages such as bearing a larger surface area which makes the release of encapsulated active substance easier by surface erosion \& diffusion and providing penetration and crossing through physiological barriers. ${ }^{23}$ Nanoparticulate systems appear more suitable for delivery to inflamed synovial tissue than microparticles due to their ability to penetrate the synovium as reported by Horisawa et al. ${ }^{24} \mathrm{~A}$ colloidal suspension of the fluoresceinamine bound nanoparticles, with a mean diameter of $265 \mathrm{~nm}$, was phagocytosed in the synovium by the macrophages infiltrated through the synovial tissues. In contrast, an aqueous suspension of the fluoresceinamine bound microparticles, with a mean diameter of $26.5 \mu \mathrm{m}$, was not phagocytosed in the macrophages and localize inflammatory responses were almost undetected. In this research, various DS loaded nanoparticle batches having a diameter range between $168.1 \pm 3.01$ to $266.1 \pm 6.3 \mathrm{~nm}$ with narrow size distribution, were produced (Table 2). The particle size values of F4 and F5 coded nanoparticle formulations showed that the effect of different stabilizers on average particle size may be one of the most significant factor depending on the formulation. After obtaining smaller nanoparticles through the usage of PVA in F5, F6 coded nanoparticle formulation was also formulated with PVA as stabilizer.

Besides the cellular interaction and barrier penetration issues, the average particle size of nanoparticles has another impact which is injectability of the nanoparticle bearing hydrogel. The intra-articular injections are usually applied via a syringe equipped with the $18 \mathrm{G}^{25}$ or $27 \mathrm{G}^{26}$ needle. These needles have a diameter of $0.84 \mathrm{~mm}-0.21 \mathrm{~mm}$ respectively and that is why the average particle size has to be small enough not to clog the needles. Since Singh et al. ${ }^{26}$ applied nanoengineered particles with average particle size of $303 \pm 13 \mathrm{~nm}$ and $500 \pm 22 \mathrm{~nm}$ intraarticularly via $27 \mathrm{G}$ needle without any clogging problem, the hydrogel formulation bearing F6 coded nanoparticle with $190.8 \pm 3.1 \mathrm{~nm}$ average particle size may be applied via syringe equipped with $18 \mathrm{G}$ or $27 \mathrm{G}$ needle in the present study.

Zeta potential which is an indicator for micro/nano particles' stability, is the estimate of the surface charge that particles gain in the dispersed state. When the zeta potential value of nanoparticles is between $\pm 30 \mathrm{mV}$, the colloidal systems show no aggregation and they form stable dispersions that depends on the repulsion forces between particles. ${ }^{27,28}$ From this point of view, nanoparticles' stability confirmed via zeta potential analysis. The zeta potential value of F6 coded formulation

Table 1. Polymeric nanoparticle formulations

\begin{tabular}{llllll} 
Code & Polymer & PLGA:PCL ratio & Surfactant & Stabilizer & PH (outer phase) \\
\hline F1 & PLGA & $1: 0$ & Tween80 & Poloxamer 188 & 7.4 \\
\hline F2 & PCL & $0: 1$ & Tween80 & Poloxamer 188 & 7.4 \\
\hline F3 & PLGA+PCL & $1: 1$ & Tween80 & Poloxamer 188 & 7.4 \\
\hline F4 & PLGA+PCL & $1: 1$ & Tween80 & Poloxamer 188 & 5.8 \\
\hline F5 & PLGA+PCL & $1: 1$ & Tween80 & PVA & 5.8 \\
\hline F6 & PLGA+PCL & $1: 1$ & Arlacel ${ }^{\circledR}-C$ & PVA & 5.8 \\
\hline
\end{tabular}

PLGA: Poly(lactic-co-glycolic acid), PCL: Poly( $\varepsilon$-caprolactone), PVA: Polyvinyl alcohol

Table 2. Particle size, polydispersity index, zeta potential and encapsulation efficiency of formulations

\begin{tabular}{lllll} 
Code & Particle size $(\mathrm{nm})$ & Polidispersity index $(\mathrm{PI})$ & Zeta potential $(\mathrm{mV})$ & Encapsulation efficiency $(\%)$ \\
\hline F1 & $169.2 \pm 2.5$ & $0.354 \pm 0.001$ & $-55.9 \pm 1.3$ & $31.5 \pm 0.5$ \\
\hline F2 & $199.5 \pm 4.9$ & $0.208 \pm 0.006$ & $-46.1 \pm 1.3$ & $37.7 \pm 0.1$ \\
\hline F3 & $168.1 \pm 3.01$ & $0.177 \pm 0.006$ & $-44.9 \pm 0.5$ & $18.4 \pm 1.2$ \\
\hline F4 & $266.1 \pm 6.3$ & $0.367 \pm 0.011$ & $-39.3 \pm 0.4$ & $24.4 \pm 1.1$ \\
\hline F5 & $195.7 \pm 3.5$ & $0.265 \pm 0.010$ & $-23.0 \pm 2.8$ & $56.1 \pm 0.4$ \\
\hline F6 & $190.8 \pm 3.1$ & $0.145 \pm 0.008$ & $-29.6 \pm 2.7$ & $89.7 \pm 0.9$ \\
\hline
\end{tabular}


was found as $-29.6 \pm 2.7 \mathrm{mV}$ which is in the theoretical $\pm 30 \mathrm{mV}$ stability range and no aggregation was observed after three months storage at $25^{\circ} \mathrm{C}$ and $60 \%$ relative humidity.

Particle size, polydispersity index and zeta potential of F6 nanoparticle formulation was measured after three months storage at $25^{\circ} \mathrm{C}, 60 \%$ relative humidity. Particle size/size distribution $(182.0 \pm 1.511 \mathrm{~nm}$ and $0.231 \pm 0.009$, respectively) and zeta potential $(-28.8 \pm 0.69)$ of $\mathrm{F} 6$ formulation was found similar.

\section{Encapsulation efficiency}

Encapsulation efficiency of the active substance is a crucial parameter for particularly expensive active substances in drug delivery systems. ${ }^{23}$ Two different methods were evaluated for determination of encapsulation efficiency. The encapsulation efficiency results of $\mathrm{F} 1$ coded formulation with indirect method and direct method are $31.5 \pm 0.5$ and $33.1 \pm 0.9 \%$, respectively. This result shows that there is no significant difference for determination of encapsulation efficiency between direct and indirect method. We have concluded that the critical experimental step which effects the results of encapsulation efficiency, obtained by different methods is the washing step that removes the drug molecules attached to nanoparticles' surface. That is why all the encapsulation efficiency experiments were carried out with indirect method which is simple, quick and accurate with the application of enough washing steps although the direct method seems more accurate for drug encapsulation analysis.

The $\mathrm{pH}$ value of external aqueous phase may have a significant effect on encapsulation process if drug substances have a $\mathrm{pH}$ dependent solubility. Since DS has pH dependent solubility such as $0.14 \mathrm{mg}$ DS is soluble in $1 \mathrm{~mL}$ of $\mathrm{pH} 5.8$ phosphate buffer and $5.15 \mathrm{mg}$ DS soluble in $1 \mathrm{~mL} \mathrm{pH} 7.4$ phosphate buffer at $23 \pm 2^{\circ} \mathrm{C}_{1}{ }^{29}$ a $\mathrm{pH}$ value which DS is less soluble in the external phase was selected in order to increase encapsulation efficiency. ${ }^{22}$ Lowering the external pH from 7.4 to 5.8 (F4) resulted with an increase on encapsulated DS by $32 \%$ and from this point on all other nanoparticle formulations (F5 and F6) were prepared with $\mathrm{pH} 5.8$ external phase which allows less DS escape to outer aqueous phase depending on less solubility.

The stability of the first emulsion $\left(W_{1} / O\right)$ plays an important role in encapsulation efficiency in the $W_{1} / O / W_{2}$ emulsion-solvent evaporation technique. Non-ionic surfactants are mostly added the inner aqueous phase. ${ }^{30}$ In this research, Arlace ${ }^{\circledR}{ }^{-} \mathrm{C}$ which is usually utilized for hydrophobic drug encapsulation, was used in first emulsification step as a surfactant and significantly increased ( $p<0.05$ ) encapsulation efficiency of DS.

Encapsulation efficiency value also varies depending on some parameters including the solubility of the active substance and the type of selected solvent and polymer. ${ }^{31}$ DS is referred as sparingly soluble in water $30^{\text {th }}$ United States Pharmacopoeia 30 and this solubility characteristic facilitates encapsulation of DS to the polymeric structure. The highest encapsulation efficiency was obtained with F6 formulation $(89.7 \% \pm 0.9)$ which is one of the most critical finding of this research. As indicated by Lai et al.' (2014) PVA was found the best stabilizer for the second emulsification step for PLGA nanoparticles and increased encapsulation of DS in F5 and F6 formulations.

Gelation temperature, $\mathrm{pH}$ and viscosity of in situ hydrogel A gelation temperature suitable for in situ gel formulations would be $30-36^{\circ} \mathrm{C}$ according to Kim et al..$^{32}$ In situ hydrogel formulation containing DS loaded nanoparticles was found in this range $\left(35.0 \pm 2.6^{\circ} \mathrm{C}\right)$ and the $\mathrm{pH}$ of this formulation was adjusted to $6.9 \pm 0.08$ with $100 \mu \mathrm{L} \mathrm{pH} 7.4$ phosphate buffer which is feasible for intra-articular injection. ${ }^{33}$ Viscosity values at $25^{\circ} \mathrm{C}$ and $37^{\circ} \mathrm{C}$ were compared and a significant increase in viscosity depending on the temperature was observed as a result of gelation $(p<0.05)$ (Figure 1).

\section{In vitro release}

Effect of polymer/polymer combination (PLGA and/or PCL) on the drug release profile was evaluated at Figure 2. The release profile of $\mathrm{F} 2$ formulation indicates that $\mathrm{PCL}$ nanoparticles have a slower release profile than PLGA nanoparticles due to PCL has more hydrophobic character and higher molecular weight as well. F3 coded formulation prepared with mixture of PLGA and PCL (1:1) released a greater amount of the drug than F1 and F2 coded formulations containing PLGA or PCL alone during the same period (Figure 2). Utilization of the polymer blends in particle production process may lead particles with different surface porosity characteristics. Cao and Shoichet ${ }^{34}$ clearly demonstrated that particles prepared with PLGA/PCL blend had considerable surface porosity compared to particles were composed of PCL or PLGA alone. The increase of the porosity on nanoparticles' surface which may be obtained by using the combination of polymers in F3 coded formulation, might lead to increased drug release. Since one of the aims of this research is providing a side effect free medication with application of the drug with as low dose as possible, all other nanoparticle formulations (F4, F5 and F6) were prepared with the combination of PLGA and PCL.

In Figure 3, effect of stabilizers and surfactants on the drug release profile was evaluated. The surfactant of inner phase has been shown to have an important effect on the drug release. Arlace ${ }^{\circledR}{ }^{-} \mathrm{C}$ including $\mathrm{F} 6$ coded formulation was sustained the release of the drug more then other formulations. In vitro release of DS was prolonged over 24 hours with F6 formulation (Figure 3). Then, F6 nanoparticles were transferred into in situ hydrogel

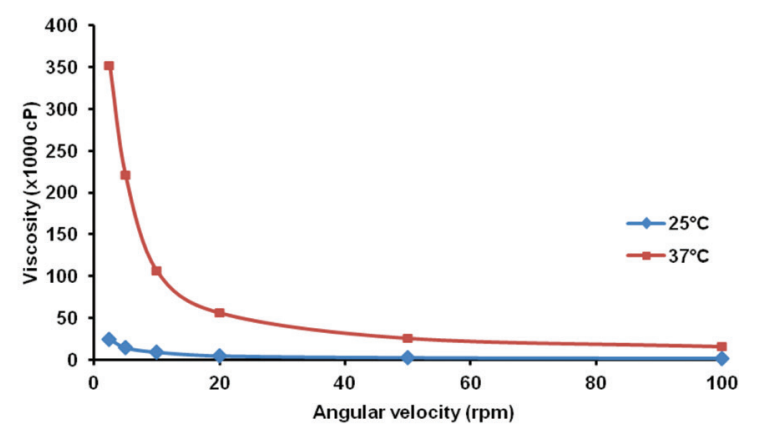

Figure 1. Viscosity versus angular velocity graphs at $25^{\circ} \mathrm{C}$ and $37^{\circ} \mathrm{C}$ 
formulation and in vitro release was repeated $(1 \mathrm{~mL}$ of hydrogel formulation contains $14 \mathrm{mg}$ of nanoparticle that is loaded with 5 mg DS). 98\% DS was released from F6 loaded in situ hydrogel in a controlled manner during 30 days (Figure 4). Similarly, nanoparticle-based topical ophthalmic gel formulation was prepared by Yang et al. ${ }^{35}$ and hydrocortisone was released from nanoparticle-gel system over 30 days. The prolonged release of the DS may be attributed to the poloxamer's property to control the release of the encapsulated drug from hydrogel. Utilization of chitosan together with poloxamer in the hydrogel formulation would be also beneficial in terms of providing bioadhesive effect at application are for stronger attachment of gelling system to articular surface. ${ }^{36}$

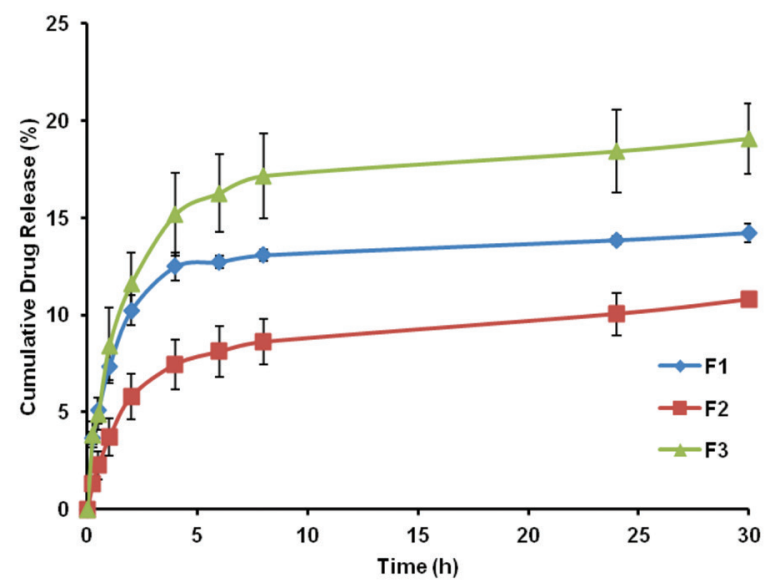

Figure 2. In vitro release profiles of F1, F2 and F3 formulations

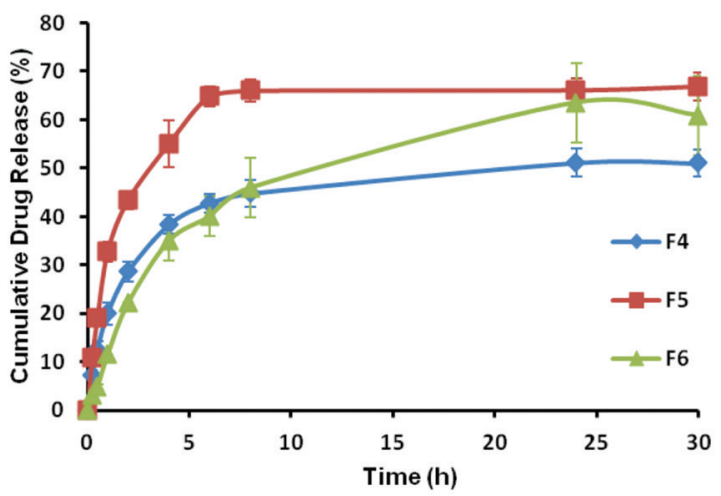

Figure 3. In vitro release profiles of F4, F5 and F6 formulations

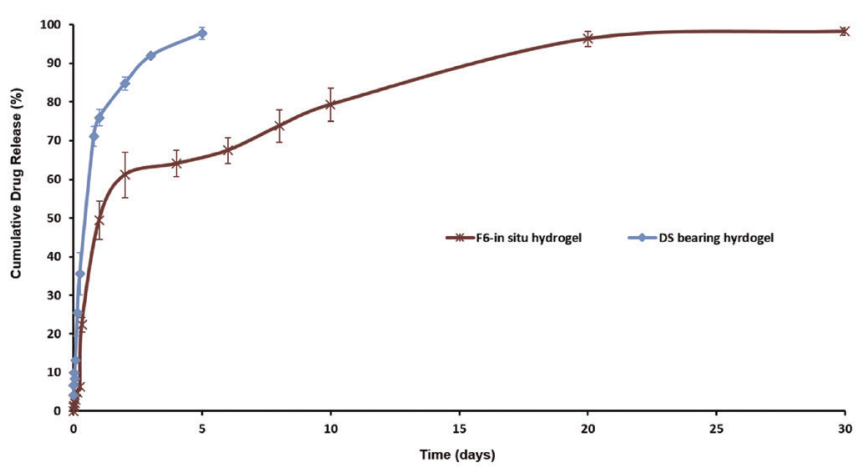

Figure 4. In vitro release profile of diclofenac sodium bearing hydrogel formulation and F6 loaded in situ hydrogel formulation
The DS loaded nanoparticles containing hydrogel's release profile was also compared with non-encapsulated DS containing hydrogel to reveal the fact if the 30 days release profile is an attribute of the utilization of nanoparticles or just an advantage of hydrogel. Figure 4 shows that non-encapsulated DS containing hydrogel provide only a 5 days release. The possible reason of obtaining a 30 days release profile with in situ gel containing nanoparticles may be the slow hydration of nanocarrier's surface while formulated in the hydrogel. When the low amount of DS released from the carrier there is another barrier which is polymeric hydrogel network, for being released to the medium. Hence, there are two different barriers to pass for DS for being released and these barriers prolong the release of DS.

The parameters and conditions of in vitro release test method which we applied, has to be controlled and standardized to obtain a valid performance indicator of formulation. A typical release test includes standardized conditions such as, hydration of dialysis membranes with release medium during 12 hours before the test, putting the same volume of either nanoparticles (suspended in $1 \mathrm{~mL}$ of release medium) or hydrogel formulations $(1 \mathrm{~mL})$, being sure that there is no air bubbles in dialysis bags, replacing the withdrawn release medium with the fresh medium and maintaining the flow of the release medium on the dialysis membrane's surface to provide gradient between the release medium and inside the membrane. The volume of the release medium has to be large enough compared to continuous phase (the volume that was put inside the membrane) to provide a faster diffusion rate compared to release rate of the drug from the nanocarrier for getting rid of obtaining a release profile depending on partition. But there is one parameter that may affect the results and may be considered as a source of error which is the continuous phase volume's change depending on the osmosis. ${ }^{37}$ Since we have used a quite small volume $(1 \mathrm{~mL})$ compared to release medium $(50 \mathrm{~mL})$ as continuous phase, the possible change at $1 \mathrm{~mL}$ volume was not a significant source of error.

The average of three repetitions for each formulation was plotted against time and error bars were presented on graphs. The error bars show the experimental range that may depend on small variations of dilution or withdrawn volume.

Although intra-articular injection is a relatively painful and expensive administration, increased dose application interval to 1 month might decrease the total cost of the treatment and also provides better patience compliance. Apart from this fact, many studies have reported severe side effects could be eliminated by utilization of local delivery. According to the data of Zhang et al. ${ }^{38}$ $80 \%$ of drug was released from locally administered polymeric micelle formulations in $24 \mathrm{~h}$. In vivo pharmacodynamic test based on both acute and adjuvant arthritis model indicated that sustained therapeutic efficacy could be achieved through the local injection of drug-loaded nanoparticles. Most importantly, local delivery of non-steroidal anti inflammatory drug could eliminate side effects such as severe gastric ulceration, which was associated with oral administration. ${ }^{38}$

\section{Differential scanning calorimetry}

DSC analyses were performed to reveal the physical state of 
DS-nanoparticles. DSC curves of DS, PLGA, PCL and lyophilized nanoparticle formulation were shown in Figure 5. The glass transition temperatures ( $\mathrm{Tg}$ ) of PLGA, PCL and nanoparticles were found $49^{\circ} \mathrm{C}, 56^{\circ} \mathrm{C}$ and $53.72^{\circ} \mathrm{C}$, respectively. Results were in agreement with the reported Tg values of PLGA and PCL in the literature. ${ }^{39,40}$ The absence of the characteristic melting point $\left(285.36^{\circ} \mathrm{C}\right)$ peaks of DS in nanoparticle formulation indicated that DS was in the amorphous state. Amorphous state suggests better drug dispersion and increased drug-matrix interactions, leading to the conclusion that reduced crystallinity is favored when slow-release kinetic is required. ${ }^{41}$

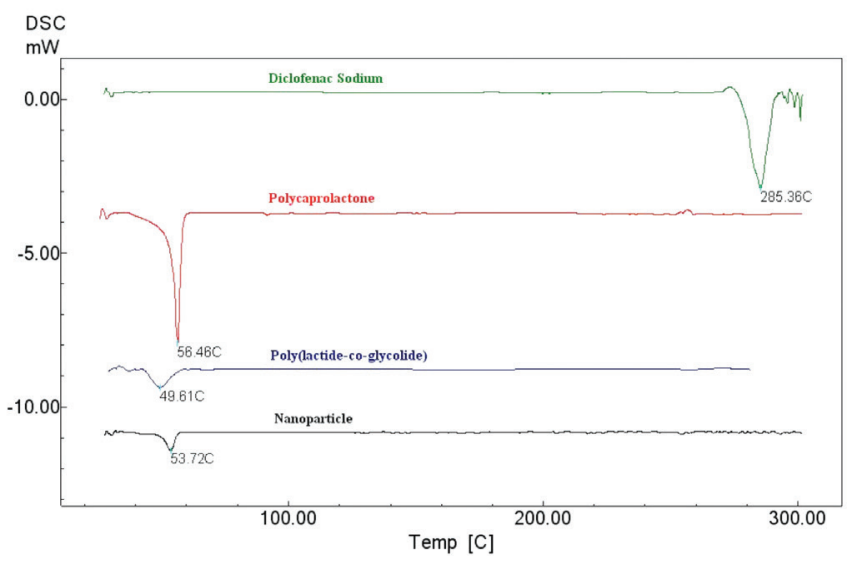

Figure 5. Differential scanning calorimetry thermograms of diclofenac sodium, poly(lactic-co-glycolic acid), poly( $\varepsilon$-caprolactone) and nanoparticles
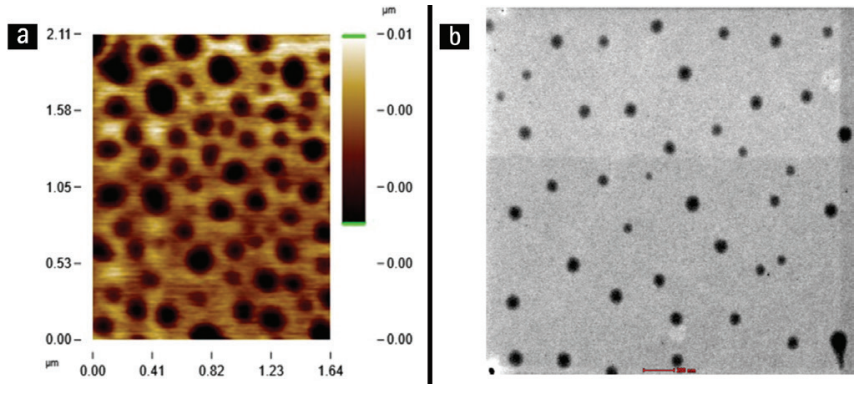

Figure 6. Atomic force microscopy image (a) and transmission electron microscopy photograph (b) of nanoparticles

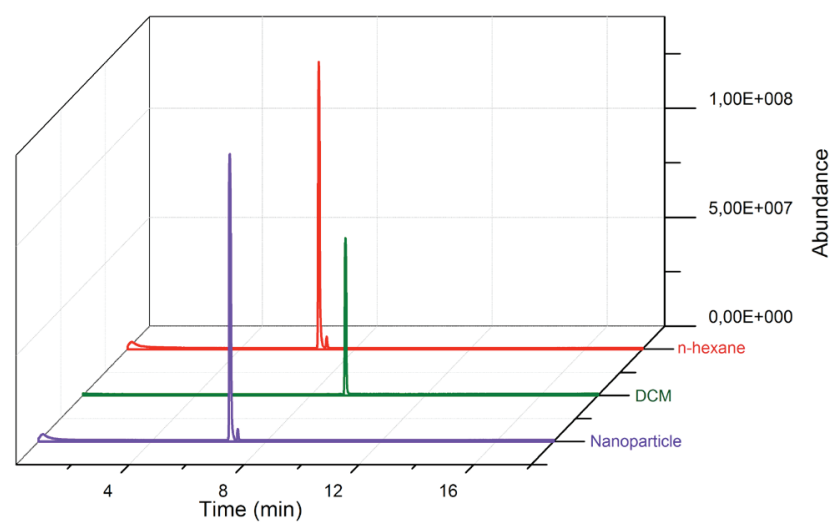

Figure 7. Gas chromatography chromatograms of pure n-hexane, pure dichloromethane and diclofenac sodium loaded nanoparticles

DCM: Dichloromethane

\section{Morphology studies}

The shape of the particles injected into the joint is important for triggering an immune response. Irregularly shaped particles have been demonstrated to promote tissue inflammation in comparison with round-shaped drug delivery systems. Round-shaped particles are to be preferred for intra-articular drug delivery. ${ }^{42}$ AFM and TEM analyses were performed for visualization of the morphology of nanoparticles. Nanoparticles were shown to have a spherical shape and there was no aggregation (Figure 6). The particle size measured by AFM and TEM confirmed the particle size results obtained by photon correlation spectroscopy.

\section{Residual dichloromethane determination by gas} chromatography analysis

During the process of nanoparticle preparation, DCM was used to dissolve polymers before mixing with an aqueous phase. Since DCM has severe toxic effects on body, the amount of residual DCM has to be controlled and determined in the developed formulations. GC chromatograms of pure n-hexane, DCM and F6 coded nanoparticle formulation are presented in Figure 7. The retention times of pure $\mathrm{n}$-hexane and DCM were at 6.74 and $9.21 \mathrm{~min}$, respectively. When the GC chromatogram of the nanoparticle formulation was examined only one peak was observed at $6.74 \mathrm{~min}$, which suggests the presence of only $\mathrm{n}$-hexane. There was no peak signal obtained that proved the existence of DCM in the nanoparticle formulation.

The GC analyses results showed that magnetic stirring and freeze drying steps during nanoparticle production process are effective enough to get rid of residual DCM.

\section{CONCLUSION}

Optimization of formulation variables used for preparation of DS loaded nanoparticles such as combination of biodegradable polymers, adding surfactant into the inner phase, adjusting the $\mathrm{pH}$ and stabilizer of the outer aqueous phase, were achieved and high encapsulation efficiency of DS was obtained. One of the most challenging intra-articular drug formulation issue ${ }^{43}$ which is quick drug release profiles of formulations during the residence time at joints, was overcome via utilizing the combination of a in situ hydrogel and polymeric nanoparticles. The projected in situ gelling system comprising DSnanoparticles has ease of application compared to microparticle based hydrogels because of having relatively small particle size and provides a controlled release of the drug over 30 days.

Detailed results and in vitro tests suggest that monthly intraarticular application of DS loaded nanoparticle bearing in situ hydrogel system could be a promising tool for the treatment of arthritis after further investigations in the future. This system holds the potential of being applicable to other drugs as a reference delivery platform in terms of enhancing patience compliance with less dose interval and also eliminating systemic side effects. 
Conflict of Interest: No conflict of interest was declared by the authors.

\section{REFERENCES}

1. Lai P, Daear W, Löbenberg R, Prenner EJ. Overview of the preparation of organic polymeric nanoparticles for drug delivery based on gelatine, chitosan, poly (d,l-lactide-co-glycolic acid) and polyalkylcyanoacrylate. Colloids Surf B Biointerfaces. 2014;118:154-163.

2. Vuddanda PR, Mishra A, Singh SK, Singh S. Development of polymeric nanoparticles with highly entrapped herbal hydrophilic drug using nanoprecipitation technique: an approach of quality by design. Pharm Dev Technol. 2015;20:579-587.

3. Elron-Gross I, Glucksam Y, Biton IE, Margalit R. A novel diclofenaccarrier for local treatment of osteoarthritis applying live-animal MRI. J Control Release. 2009;135:65-70.

4. Liu R, Sun L, Fang S, Wang S, Chen J, Xiao X, Liu C. Thermosensitive in situ nanogel as ophthalmic delivery system of curcumin: development, characterization, in vitro permeation and in vivo pharmacokinetic studies. Pharm Dev Technol. 2016;21:576-582.

5. Kim SR, Ho MJ, Lee E, Lee JW, Choi YW, Kang MJ. Cationic PLGA/ Eudragit RL nanoparticles for increasing retention time in synovial cavity after intra-articular injection in knee joint. Int $\mathrm{J}$ Nanomedicine. 2015;10:5263-5271.

6. Abdelkader H, Mansour HF. Comparative studies for ciprofloxacin hydrochloride pre-formed gels and thermally triggered (in situ) gels: in vitro and in vivo appraisal using a bacterial keratitis model in rabbits. Pharm Dev Technol. 2015;20:410-416.

7. Basaran B, Bozkir A. Thermosensitive and pH induced in situ ophthalmic gelling system for ciprofloxacin hydrochloride: hydroxypropyl- $\beta$ cyclodextrin complex. Acta Pol Pharm. 2012;69:1137-1147.

8. Soni G, Yadav KS. High encapsulation efficiency of poloxamer-based injectable thermoresponsive hydrogels of etoposide. Pharm Dev Technol. 2014;19:651-661.

9. Sweetman SC. Martindale the complete drug reference, thirty-sixth ed, Pharmaceutical Press, London, 2009.

10. Arias L, Lopez-Viotaa M, Lopez-Viota J, Delgado AV. Development of iron/ethylcellulose (core/shell) nanoparticles loaded with diclofenac sodium for arthritis treatment. Int J Pharm. 2009;382:270-276.

11. Olivier JC. Drug Transport to Brain with Targeted Nanoparticles. NeuroRx. 2005;2:108-119.

12. Khanal S, Adhikari U, Rijal NP, Bhattarai SR, Sankar J, Bhattarai N. pH-Responsive PLGA Nanoparticle for Controlled Payload Delivery of Diclofenac Sodium. J Funct Biomater. 2016;7. pii: E21

13. Schmolka IR. Artificial skin I Preparation and properties of pluronic F-127 gels for treatment of burns. J Biomed Mater Res. 1972;6:571-582.

14. Baloglu E, Karavana SY, Senyigit ZA, Guneri T. Rheological and mechanical properties of poloxamer mixtures as a mucoadhesive gel base. Pharm Dev Technol. 2011;16:627-636.

15. Mora M, Lopez LR, Gamisans X, Gabriel D. Coupling respirometry and titrimetry for the characterization of the biological activity of a SO-NR consortium. Chemical Eng J. 2014;251:111-115.

16. El-Zahaby SA, Kassem AA, El-Kamel AH. Formulation and in vitro evaluation of size expanding gastro-retentive systems of levofloxacin hemihydrate. Int J Pharm. 2014;464:10-18.
17. Chen Z, Liu D, Wang J, Wu L, Li W, Chen J, Cai BC, Cheng H. Development of nanoparticles-in-microparticles system for improved local retention after intra-articular injection. Drug Deliv. 2014;21:342-350.

18. Al-Tahami K. Preparation, characterization, and in vitro release of ketoprofen loaded alginate microspheres. Int J App Pharm. 2014;6:4-7.

19. Koopaei MN, Mostafavi SH, Amini M, Khorramizadeh MR, Tehrani MJ, Atyabi F, Dinarvand R. Docetaxel Loaded PEG-PLGA Nanoparticles: Optimized Drug Loading, In vitro Cytotoxicity and In vivo Antitumor Effect. Iran J Pharm Res. 2014;13:819-833.

20. Devrim B, Bozkir A. Design and evaluation of hydrophobic ion-pairing complexation of lysozyme with sodium dodecyl sulfate for improved encapsulation of hydrophilic peptides/proteins by lipid-polymer hybrid nanoparticles. J Nanomed Nanotechnol. 2015;6:259.

21. Seo JM, Kim EB, Hyun MS, Kim BB, Park TJ. Self-assembly of biogenic gold nanoparticles and their use to enhance drug delivery into cells. Colloids Surf B Biointerfaces. 2015;135:27-34.

22. Oz UC, Devrim B, Bozkir A, Canefe K. Development of reconstitutable suspensions containing diclofenac sodium-loaded microspheres for pediatric delivery. J Microencapsul. 2015;32:317-328.

23. Zhang Z, Feng SS. The drug encapsulation efficiency, in vitro drug release, cellular uptake and cytotoxicity of paclitaxel-loaded poly(lactide)tocopherly polyethylene glycol succinate nanoparticles. Biomaterials. 2006;27:4025-4033.

24. Horisawa E, Kubota K, Tuboi I, Sato K, Yamamoto H, Takeuchi H, Kawashima Y. Size-dependency of DL-lactide/glycolide copolymer particulates for intra-articular delivery system on phagocytosis in rat synovium. Pharm Res. 2002;19:132-139.

25. Rifat SF, Moeller JL. Injection and aspiration techniques for the primary care physician. Compr Ther. 2002;28:222-229.

26. Singh A, Agarwal R, Diaz-Ruiz CA, Willet NJ, Wang P, Lee LA, Wang Q, Guldberg RE, Garcia AJ. Nanoengineered particles for enhanced intra-articular retention and delivery of proteins. Adv Healthc Mater. 2014;3:1562-1567, 1525.

27. Celia C, Cosco D, Paolino D, Fresta M. Nanoparticulate devices for brain drug delivery. Med Res Rev. 2011;31:716-756.

28. Xie S, Zhu L, Dong Z, Wang X, Wang Y, Li X, Zhou W. Preparation, characterization and pharmacokinetics of enrofloxacin-loaded solid lipid nanoparticles: influences of fatty acids. Colloids Surf B Biointerfaces. 2011;83:382-387.

29. Chuasuwan B, Binjesoh V, Polli JE, Zhang H, Amidon GL, Junginger HE, Midha KK, Shah VP, Stavchansky S, Dressman JB, Barends DM. Biowaiver monographs for immediate release solid oral dosage forms: diclofenac sodium and diclofenac potassium. J Pharm Sci. 2009;98:1206-1219.

30. Mohammadi-Samani S, Taghipour B. PLGA micro and nanoparticles in delivery of peptides and proteins; problems and approaches. Pharm Dev Technol. 2015;20:385-393.

31. Allemen E, Gurny R, Leroux JC. Biodegredable Nanoparticles of Poly(lactic acid) and Poly(lactic-co-glycolic acid) for parenteral administration, in: H.A. Lieberman. Rieger MM, Banker GS (Eds.), Pharmaceutical Dosage Forms: Disperse Systems, 1998;163-193.

32. Kim EY, Gao ZG, Park JS, Li H, Han K. rhEGF/HP-beta-CD complex in poloxamer gel for ophthalmic delivery. Int J Pharm. 2002;233:159-167.

33. Petit A, Redout EM, van de Lest CH, de Grauw JC, Müller B, Meyboom $R$, van Midwoud $P$, Vermonden T, Hennik WE, van Weeren PR. Sustained intra-articular release of celecoxib from in situ forming gels made of acetyl-capped PCLA-PEG-PCLA triblock copolymers in horses. Biomaterials. 2015;53:426-436. 
34. Cao X, Shoichet MS. Delivering neuroactive molecules from biodegradable microspheres for application in central nervous system disorders. Biomaterials. 1999;20:329-339.

35. Yang X, Trinh HM, Agrahari V, Sheng Y, Pal D, Mitra AK. NanoparticleBased Topical Ophthalmic Gel Formulation for Sustained Release of Hydrocortisone Butyrate. AAPS PharmSciTech. 2016;17:294-306.

36. Suchaoin W, Bonengel S, Grießinger JA, Pereira de Sousa I, Hussain S, Huck CW, Bernkop-Schnürch A. Novel bioadhesive polymers as intraarticular agents: Chondroitin sulfate-cysteine conjugates. Eur J Pharm Biopharm. 2016;101:25-32.

37. Washington C. Evaluation of non-sink dialysis methods fort he measurement of drug release from colloids: effects of drug partition. Int J Pharm. 1989;56:71-74.

38. Zhang JX, Li SH, Li XH, Qiu LY, Li XD, Li XJ, Jin Y, Zhu KJ. Physicochemical characterization, in vitro, and in vivo evaluation of indomethacin-loaded nanocarriers self-assembled by amphiphilic polyphosphazene. J Biomed Mater Res. A 2008;86:914-925.
39. Mirdailami O, Khoshayand MR, Soleimani M, Dinarvand R, Atyabi F. Release optimization of epidermal growth factor from PLGA microparticles. Pharm Dev Technol. 2014;19:539-547.

40. Wang T, Li M, Gao H, Wu Y. Nanoparticle carriers based on copolymers of poly ( $\varepsilon$-caprolactone) and hyperbranched polymers for drug delivery. J Colloid Interface Sci. 2011;353:107-115.

41. Omwoyo WN, Ogutu B, Oloo F, Swai H, Kalombo L, Melariri P, Mahanga GM, Gathirwa JW. Preparation, characterization, and optimization of primaquine-loaded solid lipid nanoparticles. Int J Nanomedicine. 2014; $9: 3865-3874$.

42. Butoescu N, Jordan O, Doelker E. Intra-articular drug delivery systems for the treatment of rheumatic diseases: A review of the factors influencing their performance. Eur J Pharm Biopharm. 2009;73:205-218.

43. Gerwin N, Hops C, Lucke A. Intraarticular drug delivery in osteoarthritis. Adv Drug Deliv Rev. 2006;58:226-242. 